(2) Open Access Full Text Article

\title{
Proposed learning strategies of medical students in a clinical rotation in obstetrics and gynecology: a descriptive study
}

This article was published in the following Dove Press journal:

Advances in Medical Education and Practice

14 November 2016

Number of times this article has been viewed

\author{
Alok Prasad \\ Aamer Mughal \\ Imran Ahmed \\ Farheen Ebrahim \\ Syed Mustafa Ali Ahmad \\ Faculty of Medicine, Imperial \\ College - London, London, UK
}

\section{Dear editor}

We note with great interest the article by Deane and Murphy ${ }^{1}$ exploring the learning drivers and strategies of medical students in a clinical rotation in obstetrics and gynecology. The article highlights key points about the motivation of medical students, and we strongly agree that extrinsic motivators, such as obtaining a good ranking to stand a better chance when applying for future jobs, are key learning drivers. We lament the relative unimportance of intrinsic motivators and we commend the authors' suggestion of considering strategies to foster more intrinsic drivers of student learning. We believe, however, that this will be difficult to implement with the intense competition prevalent at every stage of a medical career, with students' motivations more likely to be of the extrinsic nature. Furthermore, from a practical standpoint, aspirations relating to future careers are often volatile or, more commonly, uncertain. This creates an environment wherein intrinsic motivators may not be applicable, and so we would argue that medical educators should focus more on aiding students to find their given area of interest, allowing the intrinsic motivation to develop naturally.

\section{Disclosure}

The authors report no conflicts of interest in this communication.

\section{Reference}

1. Deane R, Murphy D. Proposed learning strategies of medical students in a clinical rotation in obstetrics and gynecology: a descriptive study. Adv Med Educ Pract. 2016;7:489-496. 


\section{Authors' reply}

\section{Richard P Deane}

Deirdre J Murphy

Department of Obstetrics and Gynecology, Trinity College Dublin, University of Dublin, Coombe Women \& Infants University

Hospital, Dublin, Republic of Ireland

\section{Correspondence: Richard P Deane}

Department of Obstetrics and Gynecology, Trinity College Dublin, University of Dublin, Coombe Women \& Infants University Hospital,

Dublin 8, Republic of Ireland

Tel +353 | 4085365

Email deaneri@tcd.ie

\section{Dear editor}

We are very grateful to Prasad et al for their interest in our paper "Proposed learning strategies of medical students in a clinical rotation in obstetrics and gynecology: a descriptive study". ${ }^{1}$ They raise two points. First, we agree that extrinsic motivation is and will continue to be a strong driver of learning among medical students for a number of reasons, including the competitive nature of career progression in medicine. Our approach in this study was not to make extrinsic motivation redundant but rather foster more intrinsic motivators alongside extrinsic motivators. We believe this approach is correct and further exploration of the role of intrinsic motivation alongside extrinsic motivation is required. Second, we agree that the career aspirations of medical students can fluctuate significantly throughout their undergraduate training. However, we do not believe that this conflicts with the concept of fostering intrinsic motivation through students defining the relevance of their learning in their future careers. In fact, we found that this exercise actually assisted students in developing their thoughts in relation to future career paths.

\section{Disclosure}

The authors report no conflicts of interest in this communication.

\section{Reference}

1. Deane R, Murphy D. Proposed learning strategies of medical students in a clinical rotation in obstetrics and gynecology: a descriptive study. Adv Med Educ Pract. 2016;7:489-496.

Dove Medical Press encourages responsible, free and frank academic debate. The content of the Advances in Medical Education and Practice 'letters to the editor' section does not necessarily represent the views of Dove Medical Press, its officers, agents, employees, related entities or the Advances in Medical Education and Practice editors. While all reasonable steps have been taken to confirm the content of each letter, Dove Medical Press accepts no liability in respect of the content of any letter, nor is it responsible for the content and accuracy of any letter to the editor.

\section{Publish your work in this journal}

Advances in Medical Education and Practice is an international, peerreviewed, open access journal that aims to present and publish research on Medical Education covering medical, dental, nursing and allied health care professional education. The journal covers undergraduate education, postgraduate training and continuing medical education including emerging trends and innovative models linking education, research, and health care services. The manuscript management system is completely online and includes a very quick and fair peer-review system. Visit http://www.dovepress.com/testimonials.php to read real quotes from published authors. 